\title{
Structural analysis of the Rio Preto fold belt (northwestern Bahia / southern Piauí), a doubly-vergent asymmetric fan developed during the Brasiliano Orogeny
}

\author{
FABRÍCIO A. CAXITO ${ }^{1}$, ALEXANDRE UHLEIN ${ }^{1}$, LUIZ F.G. MORALES ${ }^{2}$, \\ MARCOS EGYDIO-SILVA ${ }^{3}$, JULIO C.D. SANGLARD ${ }^{1}$, TATIANA G. DIAS ${ }^{1}$ and MONICA C.O. MENDES ${ }^{1}$ \\ ${ }^{1}$ Departamento de Geologia, Instituto de Geociências, Universidade Federal de Minas Gerais, \\ Av. Antônio Carlos, 6627, 31270-901 Belo Horizonte, MG, Brasil \\ ${ }^{2}$ Géosciences Montpellier, UMR 5243 - CC 60, Université Montpellier 2, Place E. Bataillon, \\ 34095 Montpellier cedex 5, France \\ ${ }^{3}$ Departamento de Mineralogia e Geotectônica, Instituto de Geociências/ USP, \\ Rua do Lago, 562, 05508-080 São Paulo, SP, Brasil
}

Manuscript received on April 29, 2013; accepted for publication on December 10, 2013

\begin{abstract}
The Rio Preto fold belt borders the northwestern São Francisco craton and shows an exquisite kilometric doubly-vergent asymmetric fan structure, of polyphasic structural evolution attributed exclusively to the Brasiliano Orogeny ( $600-540 \mathrm{Ma})$. The fold belt can be subdivided into three structural compartments: The Northern and Southern compartments showing a general NE-SW trend, separated by the Central Compartment which shows a roughly E-W trend. The change of dip of $\mathrm{S}_{2}$, a tight crenulation foliation which is the main structure of the fold belt, between the three compartments, characterizes the fan structure. The Central Compartment is characterized by sub-vertical mylonitic quartzites, which materialize a system of low-T strike slip shear zones (Malhadinha - Rio Preto Shear Zone) crosscutting the central portion of the fold belt. In comparison to published analog models, we consider that the unique structure of the Rio Preto fold belt was generated by the oblique, dextral-sense interaction between the Cristalândia do Piauí block to the north and the São Francisco craton to the south.
\end{abstract}

Key words: Brasiliano Orogeny, doubly-vergent fan, Rio Preto fold belt, São Francisco craton, structural analysis.

\section{INTRODUCTION}

Doubly-vergent asymmetric fans are an unusual and interesting feature of many thrust-and-fold belts around the world (e.g. Koons 1990, Willett et al. 1993, McClay and Whitehouse 2004, McClay et al. 2004). The structural analysis and understanding of the causes that lead to the development of such structures is important for models of tectonic

Correspondence to: Fabrício de Andrade Caxito

E-mail: boni@ufmg.br evolution within orogenic and foreland areas, as well as for the exploration of hydrocarbon fields which are contained within these belts.

In Brazil, the Rio Preto fold belt, which border the northwestern margin of the São Francisco craton (Figure 1 and Figure 2; Almeida 1977, Alkmim 2004), is an example of a kilometric doubly-vergent asymmetric fan that serves as an exquisite natural laboratory to study such structures, which, in this scale, are uncommon in the context of the thrust- 
and-fold belts that surround the São Francisco craton. In this paper, we aim to contribute with new structural data collected within this area, whose analysis will further be used as a background for the understanding of the causes of development of this structure within the context of the Brasiliano Orogeny ( 600-540 Ma).

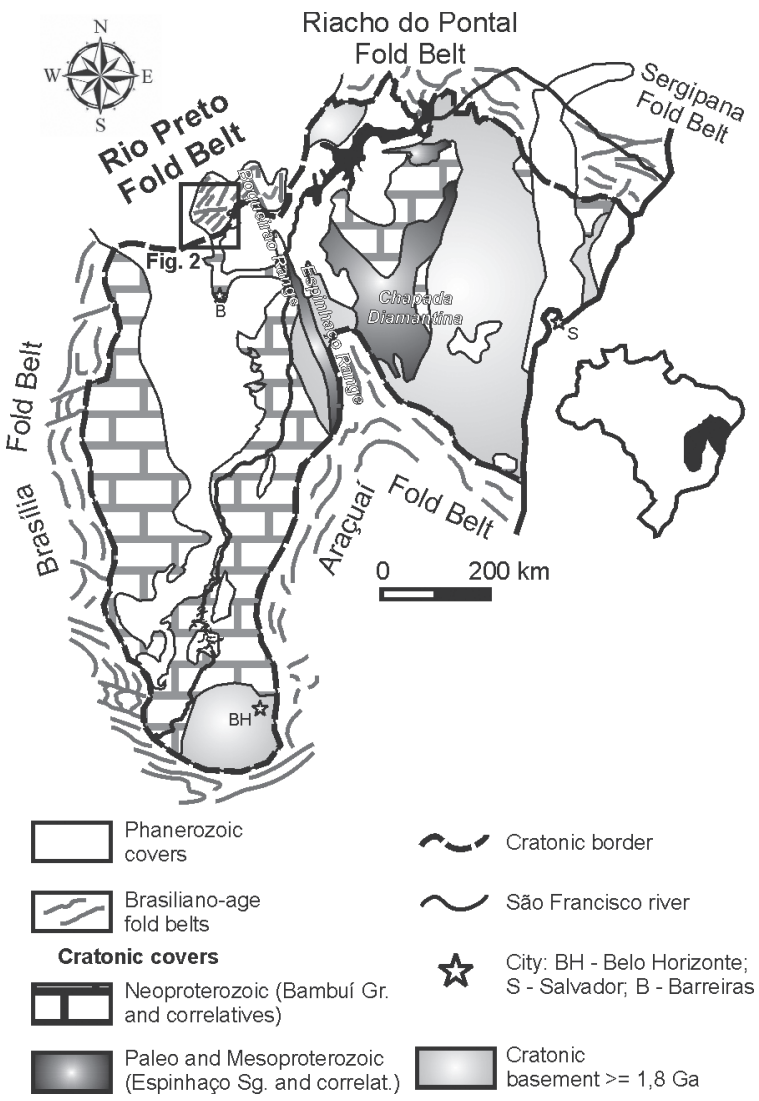

Figure 1 - The São Francisco craton and surrounding fold belts. The rectangle indicates the location of Fig. 2. Modified from Alkmim (2004).

The Rio Preto fold belt (Figure 2) is composed by the Cristalândia do Piauí Complex to the north, representing the basement of the fold belt, and the Formosa and Canabravinha formations, which represent Proterozoic metasedimentary sequences of the supracrustal structure of the fold belt (Egydio-Silva 1987, Egydio-Silva et al. 1989, Caxito 2010, Caxito et al. 2012a). The Cristalândia do Piauí Complex is composed mainly by Neoarchaean $(\sim 2.8 \mathrm{Ga})$ to Paleoproterozoic $(\sim 2.0-1.9 \mathrm{Ga})$ biotite-gneiss and amphibolite (Egydio-Silva et al. 1989, Caxito et al. 2012a). The Formosa Formation is composed by garnetmica schist, quartzite, metachert, greenschist and epidote-amphibolite intercalations, the latter dated at $1,961 \pm 11 \mathrm{Ma}$ by LA-ICP-MS U-Pb zircon analysis (Caxito et al. 2012a), thus suggesting an Orosirian age for this unit. The Canabravinha Formation is a km-thick rift sequence composed by metagraywacke, metaturbidite, quartzite, phyllite, and metadiamictite intercalations. The maximum age of deposition of this sequence is around $850 \mathrm{Ma}$, according to the youngest detrital zircon population dated by the U-Pb LA-ICP-MS method (Caxito et al. 2012a, Caxito et al. 2014). This unit might correlate with other diamictite-bearing units within and around the São Francisco craton (Caxito et al. 2012b).

All of the above stratigraphic units were subjected to greenschist facies metamorphism and deformation, which stacked the metasedimentary sequences together through tectonic contacts such as oblique and reverse faults (Figure 2). Coarse biotite and muscovite grains from all three units, parallel to the main foliation of the fold belt $\left(\mathrm{S}_{2}\right)$, yielded K-Ar ages around 600-540 Ma (EgydioSilva 1987). This geochronological data indicates a Neoproterozoic (Brasiliano-age) development for the main structure throughout the fold belt.

\section{MATERIALS AND METHODS}

Three types of aerial imagery were used in the stage of photogeological interpretation which preceded field work: Nine stereographic pairs (lateral aerial view photos) in the 1:70.000 scale from a 1968 flight; LANDSAT-7 2000 30-m resolution radar imagery; and a digital terrane elevation model generated using Golden Software Surfer $8^{\odot}$, using topographic data from the SRTM mission (http://seamless.usgs.gov), with a resolution of 3" (90 meters). 


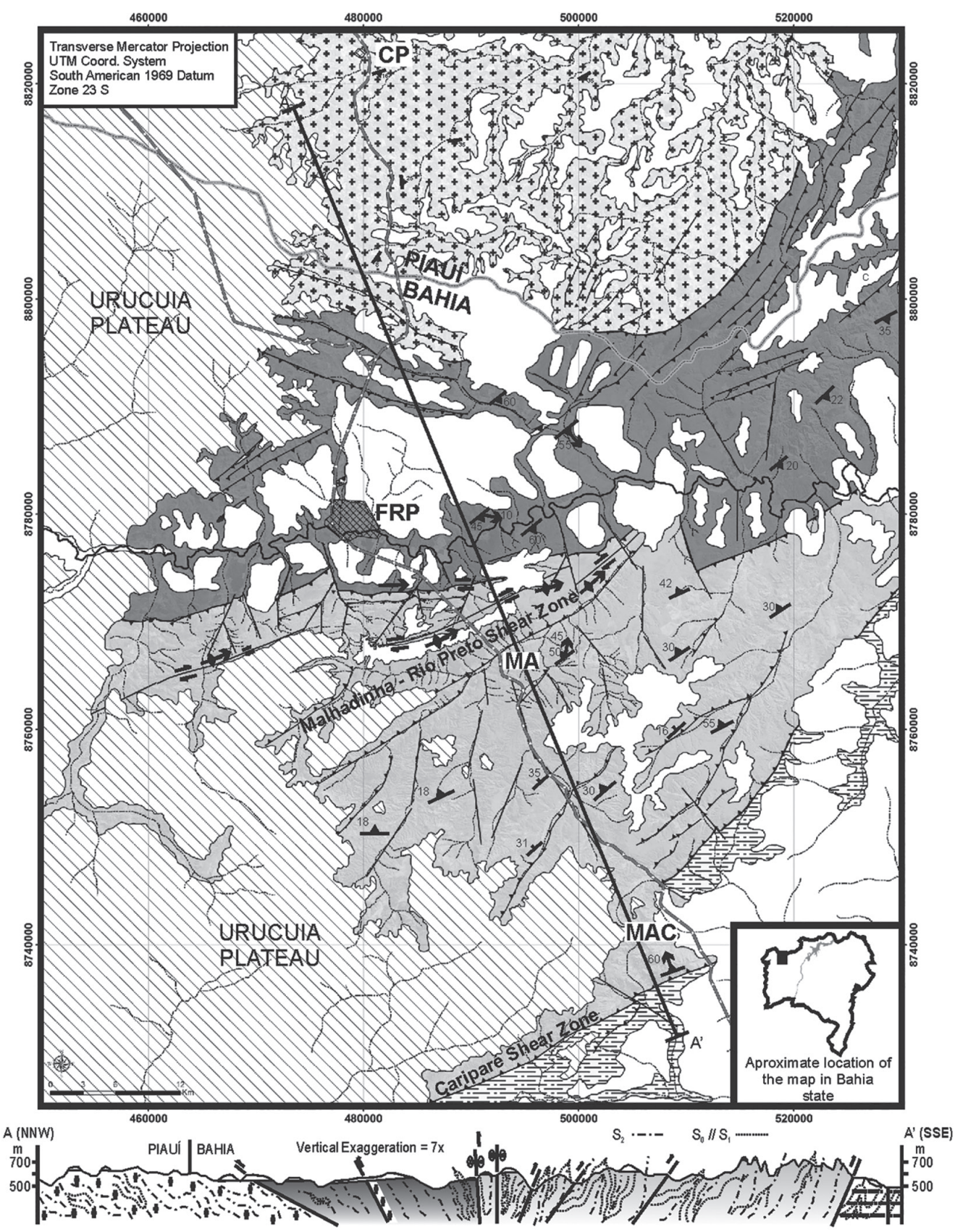

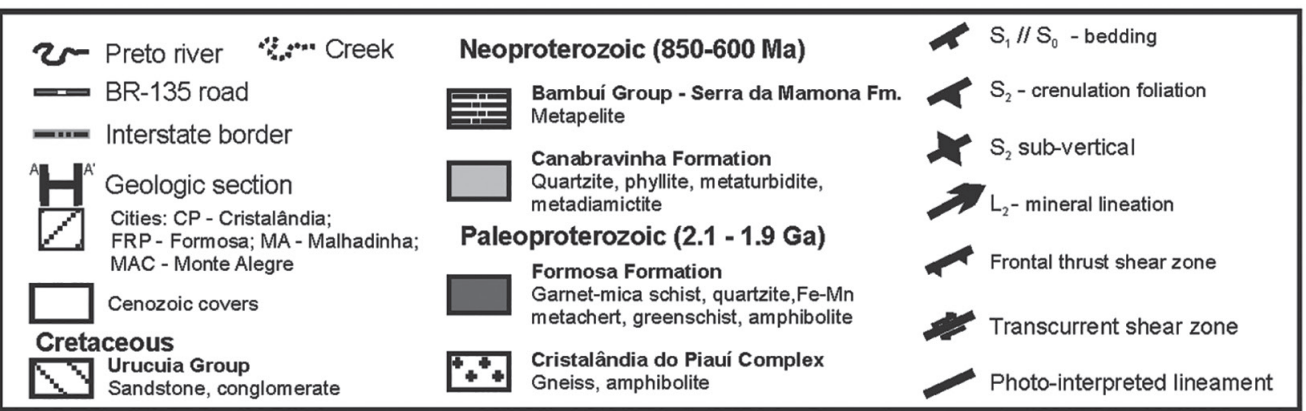

Figure 2 - Geological map and cross section of the Rio Preto fold belt. 
For the microstructural description of the rock units, 50 thin sections from selected samples were made. Samples were oriented and collected in the field according to the procedures of Passchier and Trouw (1996). The lattice preferred orientation (LPO) analysis of two quartzite oriented sections was performed at Université de Montpellier II, France, through the electron backscatter diffraction (EBSD) technique, using a JEOL JSM 5600 scanning electron microscope equipped with an Oxford Instruments/HKL Nordlys EBSD detector and Channel $5^{\circledR}$ software.

\section{RESULTS}

PHOTOLINEAMENT INTERPRETATION

A photolineament map of the area was developed through the analysis of aerial imagery, with emphasis on planar and linear positive and negative features. According to the orientation of the photolineaments, the area can be subdivided into three sub-compartments: Northern, Central and Southern (Figure 3), separated by large (kilometric) negative lineaments interpreted as disruptive structures. The Northern and Southern compartments show a prevalent NE-SW structural trend, while the Central compartment shows an E-W trend.

The positive photolineaments show a strong correlation with the most penetrative metamorphic foliation $\left(S_{2}\right)$ throughout the area, and for this reason in Figure 3 the pole stereograms for this structure are represented for each compartment, along with the respective $L_{2}$ mineral and stretching lineations.
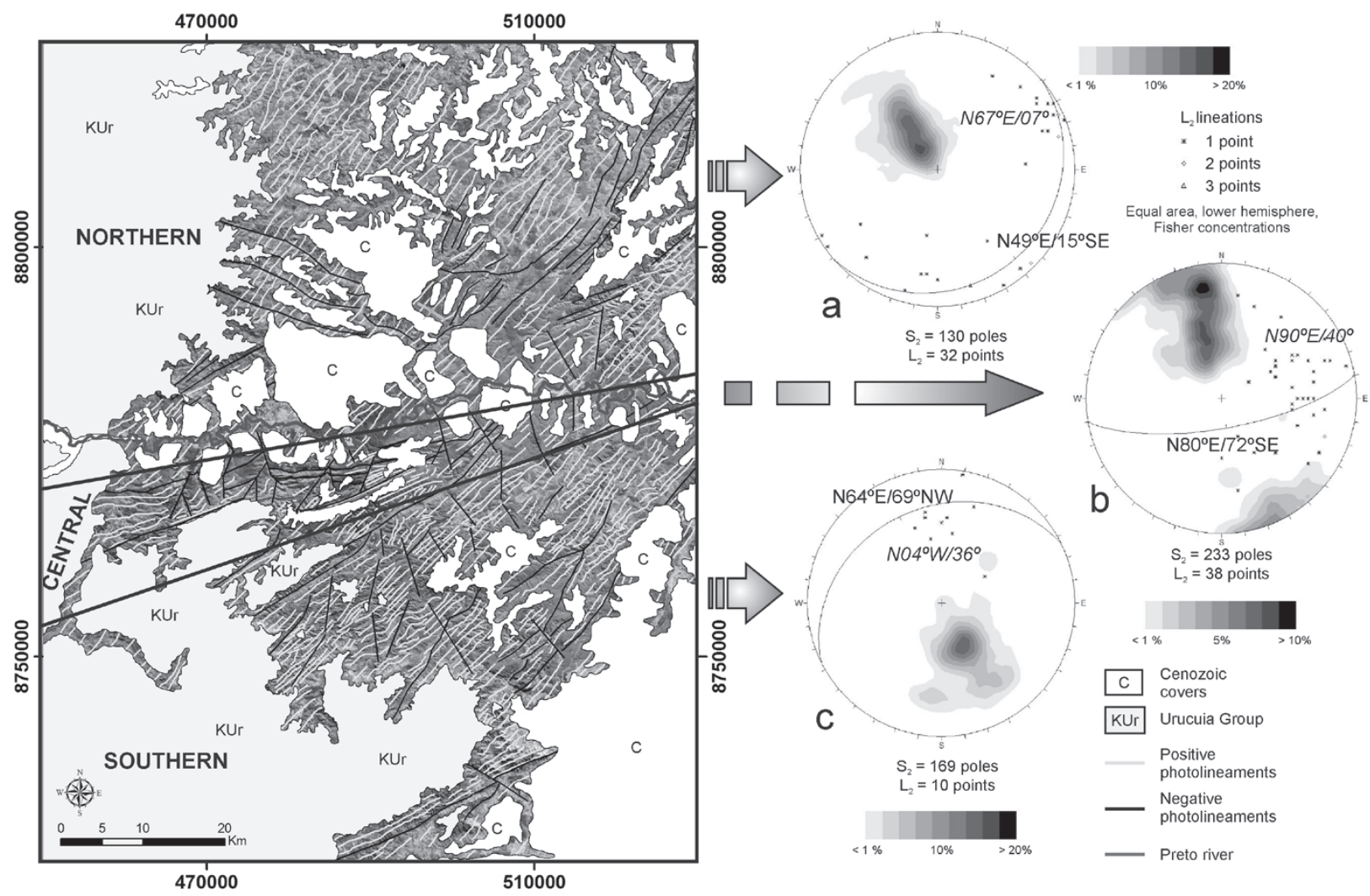

Figure 3 - Photolineament map and structural compartmentation of the Rio Preto fold belt, with isoareal contour stereograms for the poles of $S_{2}$ and scattered points for $L_{2}$ for a) Northern, b) Central and c) Southern Compartment. The attitudes in each stereogram represent the modal maximum for $\mathrm{S}_{2}$ and $\mathrm{L}_{2}$ (the latter in italics). Positive lineaments correspond to positive relief in the field, often coincident with bedding or metamorphic foliation, while negative lineaments correspond to negative relief, often coincident with fractures, faults or shear zones. 


\section{STRUCTURAL ACQUIS}

Three secondary foliations are recognizable throughout the Rio Preto fold belt (Egydio-Silva 1987; Figure 4a). The main planar structure is a tight and penetrative, milimetrically spaced axial-plane crenulation foliation $\left(\mathrm{S}_{2}\right)$, which passes gradatively, from north to south, from a coarse schistosity in the Formosa Formation rocks, to a crenulation cleavage in the southern reaches of the Canabravinha Formation, and then finally to a slaty cleavage in the metapelites of the Serra da Mamona Formation, Bambuí Group. For each structural compartment, $\mathrm{S}_{2}$ shows a distinct modal maximum (Figure 3). The development of $S_{2}$ happened alongside quartz dynamics recrystallization, muscovite, chlorite, almandine and spessartite blastesis. Thus, $\mathrm{S}_{2}$ is closely related to the main metamorphic event of the Rio Preto fold belt. The $\mathrm{L}_{2}$ set represents mineral lineations (mica, chlorite, amphibole, opaques) and stretching lineations (crystals and quartz aggregates) within the $\mathrm{S}_{2}$ planes. $\mathrm{L}_{2}$ presents distinct attitudes for each structural compartment (Figure 3).

When the $\mathrm{S}_{2}$ planes are locally millimetricaly spaced, a precedent foliation can be observed in the microlithons $\left(\mathrm{S}_{1} / / \mathrm{S}_{0}\right)$, showing microfolds whose flanks are sectioned by $\mathrm{S}_{2} . \mathrm{S}_{1}$ is a continuous foliation invariably parallel to bedding $\left(\mathrm{S}_{0}\right)$, materialized by the flattening of quartz crystals and preferential orientation of fine-grained white mica. The $\mathrm{S}_{0} / / \mathrm{S}_{1}$ poles concentrate at the northwest and southeast quadrants, with modal maxima at $\mathrm{N} 64^{\circ} \mathrm{E} / 69^{\circ} \mathrm{NW}$ and $\mathrm{N} 79^{\circ} \mathrm{E} / 65^{\circ} \mathrm{SE}$ (Figure 5c).

$\mathrm{S}_{3}$ is a centimetric to decimetric spaced crenulation or fracture cleavage, axial plane to smooth and open folds and undulations of $\mathrm{S}_{2} . \mathrm{S}_{3}$ planes commonly spread out in a discontinuous, sometimes en echelon fashion, and at places are related to northwest-verging thrust faults and fractures (Figure 4f). The attitude of $S_{3}$ doesn't vary considerably in between the three structural compartments, showing a modal maximum at $\mathrm{N} 83^{\circ} \mathrm{W} / 32^{\circ} \mathrm{SW}$ (Figure 5e). $\mathrm{S}_{3}$ is materialized, in general, through the preferential accumulation of fine opaque minerals in discreet planes.

The intersecting lineations $\mathrm{S}_{1} \times \mathrm{S}_{2}$ and $\mathrm{S}_{2}$ $x \quad S_{3}$ were considered alongside direct fold axis measures related to $\mathrm{S}_{2}$ and $\mathrm{S}_{3}$, respectively (Figure $5 \mathrm{~d}$ and $\mathrm{f}$ ). The $\mathrm{b}_{2}$ axis presents a modal maximum at $\mathrm{S} 55^{\circ} \mathrm{W} / 08^{\circ}$, close to the constructed axis for the $\mathrm{S}_{0} / / \mathrm{S}_{1}$ stereogram (Figure $5 \mathrm{c}$ ). The $\mathrm{b}_{3}$ axis at N81 ${ }^{\circ}$ E $/ 03^{\circ}$ characterizes the folding events related to $S_{2}$ and $\mathrm{S}_{3}$ as approximately coaxial.

Joints and fractures attitudes collected in the field show modal maxima at $\mathrm{N} 72^{\circ} \mathrm{E} / 85^{\circ} \mathrm{NW}$ and $\mathrm{N} 23^{\circ} \mathrm{W} / 77^{\circ} \mathrm{SW}$, similar to late-stage quartz veins at $\mathrm{N} 77^{\circ} \mathrm{E} / 76^{\circ} \mathrm{NW}$ (rosette diagrams of Figure $5 \mathrm{a}$ and $\mathrm{b}$ ). In remote sensing imagery some of the observed lineaments coincide with these trends, especially at the Central compartment, where these lineaments displace portions of the tectonic contact between the Canabravinha and Formosa formations. Thus, these brittle structures probably represent a late stage of the compressional progressive deformation.

\section{SOUTHERN COMPARTMENT}

Structures of the Southern Compartment show modal maxima at $\mathrm{S}_{2}=\mathrm{N} 64^{\circ} \mathrm{E} / 29^{\circ} \mathrm{NW}$ and $\mathrm{L}_{2}$ $=\mathrm{N} 04^{\circ} \mathrm{W} / 36^{\circ}$ (Figure 3a); thus characterizing a predominantly frontal kinematics. The most meridional continuous lineament corresponds to the Cariparé Shear Zone, which is the tectonic contact between the Canabravinha and Serra da Mamona formations. The stretching lineation marked by deformed clasts of the diamictites of the Canabravinha Formation which occur adjacent to this shear zone is concentrated in the NNW quadrant (Egydio-Silva 1987), thus configurating a down-dip lineation and characterizing the shear zone as a frontal thrust with tectonic transport from NNW to SSE. 

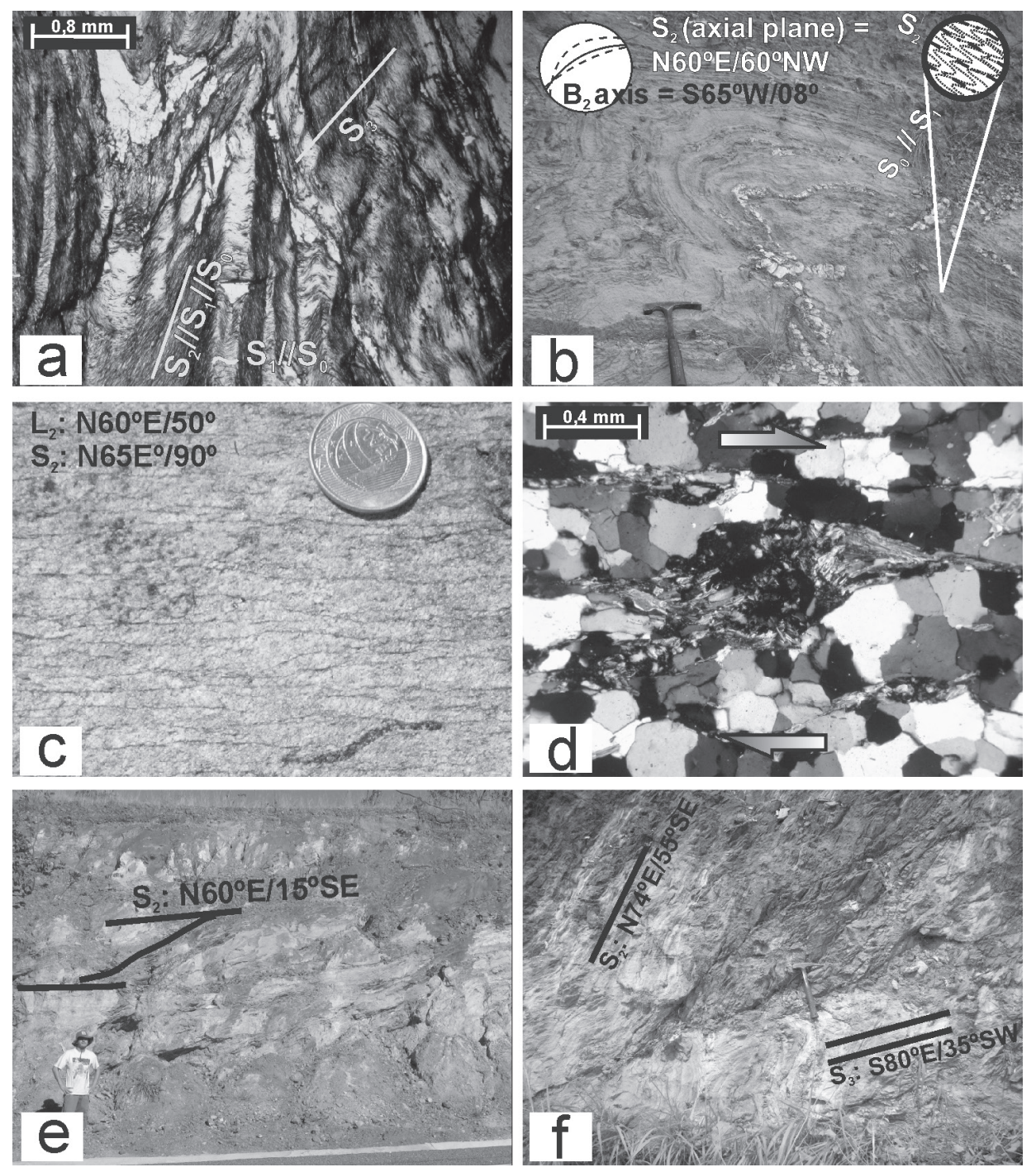

Figure 4 - Structural features of the Rio Preto fold belt. a) Photomicrography showing the microscopic relationships between the three deformational foliations, in fold hinge zones of a Canabravinha Formation phyllite, Southern Compartment; b) tight fold of the Canabravinha Formation, Southern Compartment; c) sub-vertical mylonitic quartzite of the Canabravinha Formation, Central Compartment, with development of S-C pairs; d) Photomicrography showing the microscopic aspect of mylonitic quartzite of the Central Compartment, with dextral shear sense indicator; e) ramp and platform geometry of thrust fronts in Formosa Formation schists, Northern Compartment; f) development of NW-verging thrust faults parallel to $\mathrm{S}_{3}$, Central Compartment. a) and d) under crossed polarizers.

In the rocks of the Canabravinha Formation of the Southern compartment, $\mathrm{S}_{2}$ is a crenulation cleavage which is parallel to the axial plane of tight to isoclinal southeast verging similar class 2 folds $\left(\mathrm{S}_{0} / / \mathrm{S}_{1}\right.$ modal maxima: $\mathrm{N} 78^{\circ} \mathrm{E} / 33^{\circ} \mathrm{NW}$ and $\mathrm{N} 84^{\circ} \mathrm{E} / 64^{\circ} \mathrm{NW}$; constructed axis: $\mathrm{S} 86^{\circ} \mathrm{W} / 06^{\circ}$; Figure $4 \mathrm{~b}$ and Figure $5 \mathrm{j}$ ). In metapelites of the Serra da Mamona Formation, $\mathrm{S}_{2}$ is a slaty cleavage which is parallel to the axial plane of tight to open horizontal normal folds. Hinge morphology varies from rounded to angular. The folds become progressively tighter in the proximities of the Cariparé Shear Zone.

CENTRAL COMPARTMENT

The Central Compartment is characterized by a change in the general trend of the photolineaments, 

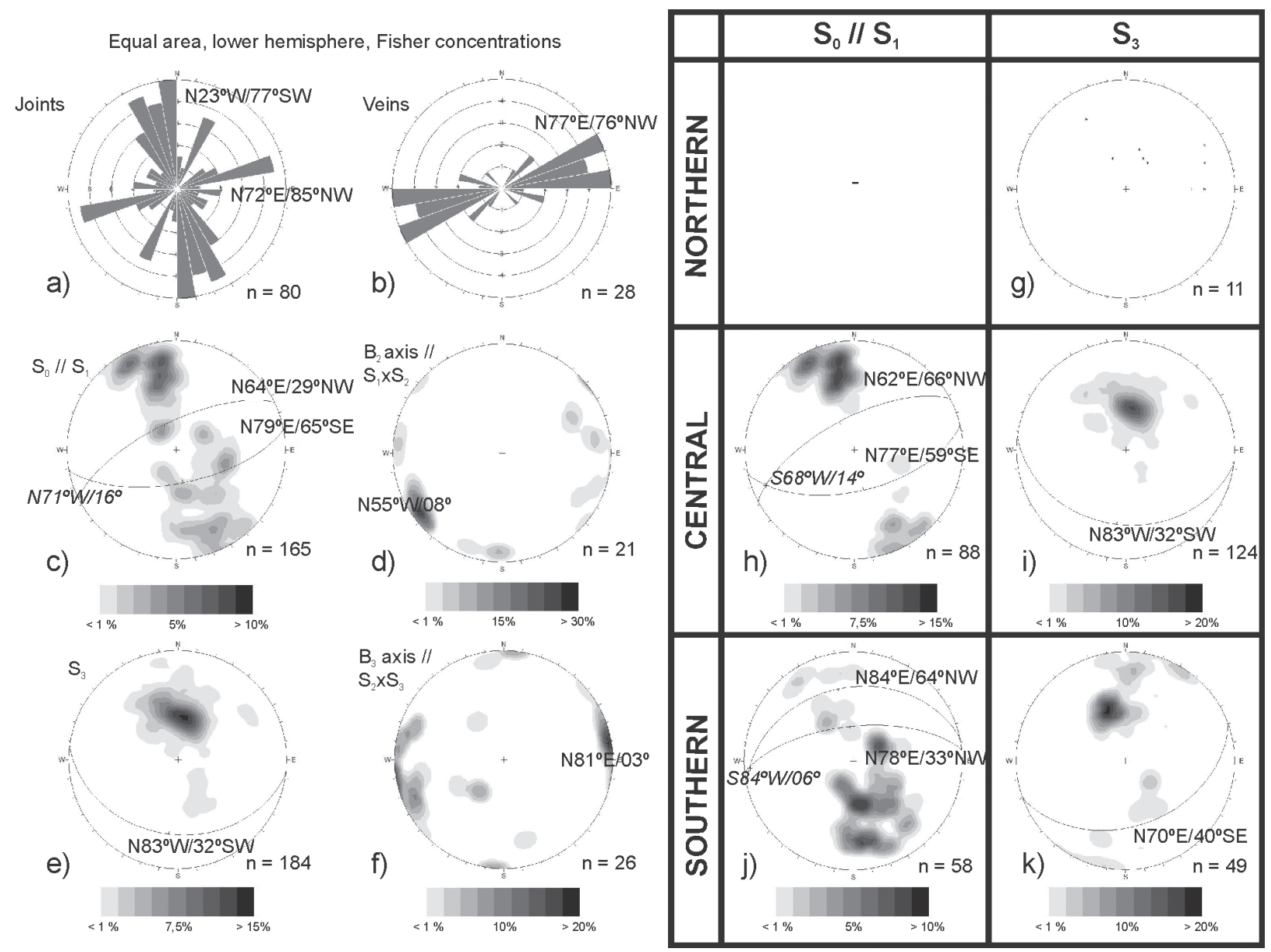

Figure 5 - Isoareal stereograms for structures of the Rio Preto fold belt.

from NE-SW to E-W (Figure 3), in the metarhythmites of the Canabravinha Formation. $\mathrm{S}_{2}$ assumes high-angle dipping to sub-vertical values $\left(\mathrm{N} 80^{\circ} \mathrm{E} / 72^{\circ} \mathrm{SE}\right)$, associated with $\mathrm{L}_{2}$ at $\mathrm{N} 90^{\circ} \mathrm{E} / 40^{\circ}$, thus suggesting the predominance of oblique kinematics (Figure 3b).

The Central compartment is separated from the Southern and Northern compartments by two main borderline lineaments (Figure 6). The southern lineament is characterized by a zone of strong transposition of $\mathrm{S}_{0} / / \mathrm{S}_{1}$ by the sub-vertical $\mathrm{S}_{2}$ foliation $\left(\mathrm{N} 65^{\circ} \mathrm{E} / 86^{\circ} \mathrm{NW}\right.$; Figure $\left.6 \mathrm{c}\right)$. Micaceous mylonitic quartzites characterize this zone, which is named Malhadinha Shear Zone. $\mathrm{L}_{2}$ presents low to medium rake, dipping $\mathrm{NE}\left(\mathrm{N} 57^{\circ} \mathrm{E} / 38^{\circ}\right)$. Most kinematic indicators analyzed in different scales (remote sensing imagery, outcrop, hand samples, thin section) indicate reverse oblique dextral shear sense, with top-to-Northwest.

The northern lineament is characterized by a disruptive zone denominated Rio Preto Shear Zone (Gonçalves Dias and Mendes 2008), with variable attitude, at most places sub-vertical, but locally dipping steeply $\mathrm{SSE}\left(\mathrm{N} 80^{\circ} \mathrm{E} / 74^{\circ} \mathrm{SE}\right.$; Figure $6 \mathrm{a}) . \mathrm{L}_{2}$ shows low to medium rake, dipping $\mathrm{NE}\left(\mathrm{N} 63^{\circ} \mathrm{E} / 36^{\circ}\right)$. The general trend is $\mathrm{E}-\mathrm{W}$ to WNW-ENE; however this structure is displaced by late-stage faults (Figure 6). It is possible that these represent scissor faults, what would explain the variable attitude of the shear zone, which is sectioned and rotated in distinct portions. This lineament is the tectonic boundary between the 
Canabravinha and Formosa formations, where the first is thrusted upon the second through the reverse oblique dextral shear zone, with top-toNorth movement. This kinematics is interpreted based on the same criteria as for the Malhadinha Shear Zone. The main structures used to determine the shear sense in these two shear zones are: "S" deflection patterns of the superficial envelope of $S_{2}$ in aerial imagery (Figure 6d), "S" pattern of S-C pairs in outcrop scale (Figure 4c), and diverse microstructures in thin section scale, such as phorphyroclasts with asymmetric tails (Figure 4d), mica-fish and foliation-fish, oblique foliation, etc.
Thus, the Central Compartment can be described as a region of intense dextral oblique transpressional movement, composed by diverse shear zones which ramify in almond-shaped forms in plain view, forming a pseudo-flower structure in a cross section view (Figure $6 e)$. This arrangement is typical of oblique to strikeslip zones of deformation, generated by the linking of diverse fault segments developed contemporaneously (Sylvester and Smith 1976, Woodcock and Schubert 1994). The two main structures are the Malhadinha and Rio Preto shear zones. Thus, for simplification, the whole Central Compartment can be understood as a shear zone system denominated Malhadinha Rio Preto Shear Zone (Figure 6).

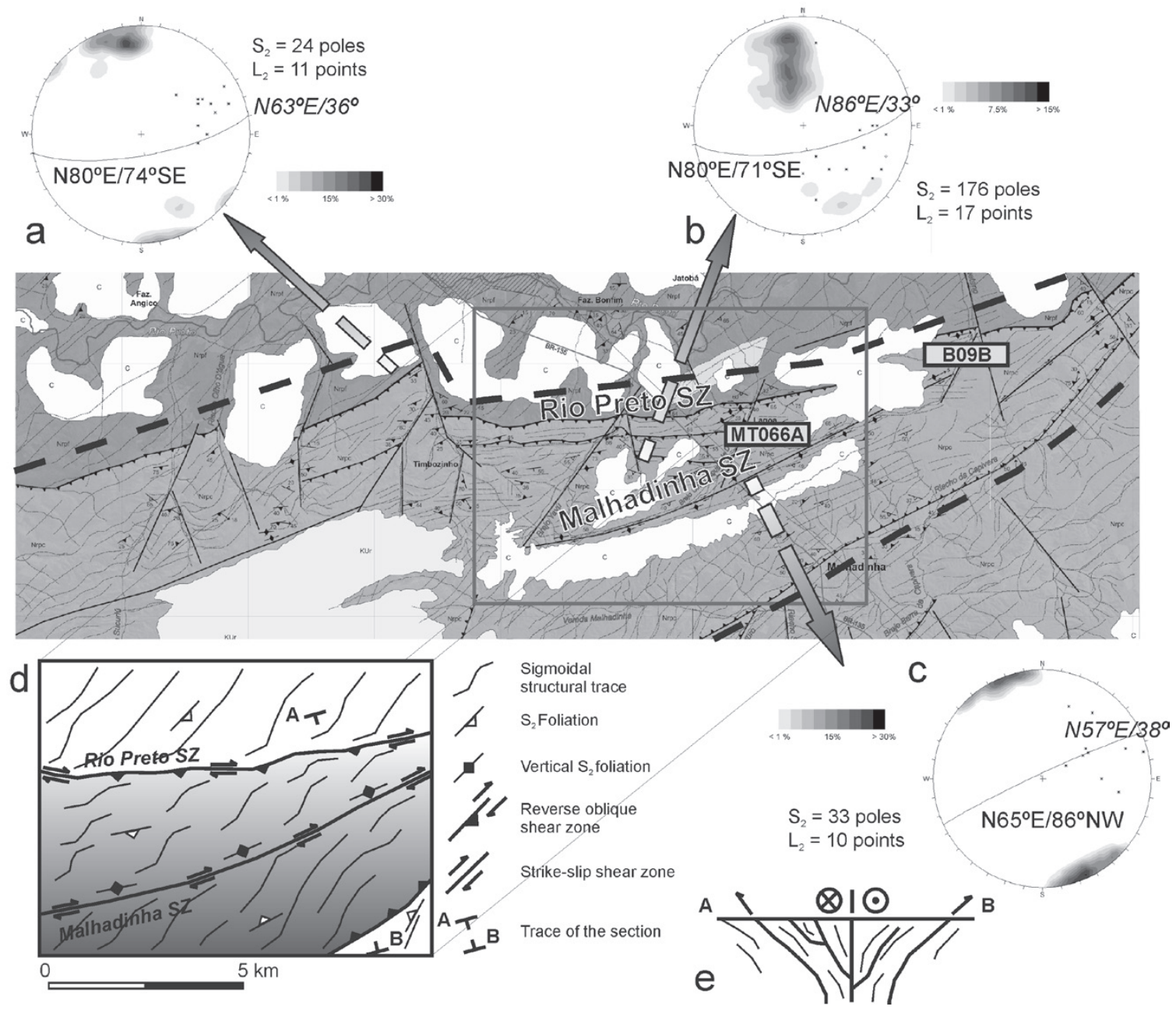

Figure 6 - Isoareal stereograms for structures in a) Rio Preto Shear Zone; b) central portion of the Central Compartment; c) Malhadinha Shear Zone. In d) and e), structural schemes of the Central Compartment, in plane and section view, respectively. 
The Lattice Preferred Orientation (LPO) of quartz grains from two mylonitic quartzite samples from the Malhadinha - Rio Preto Shear Zone were analyzed in order to characterize the deformational process in this zone of concentrated deformation. Figure 7 shows the pole figures with distribution of cand a-axis of quartz crystals from samples B09B and MT066A (see location in Figure 6). The distribution of the crystallographic axis suggests that there is a preferential orientation on the crystallographic structure of quartz, and that this orientation is asymmetric in relation to the external reference axis (the $\mathrm{x}-\mathrm{y}$ plane is parallel to the $\mathrm{S}_{2}$ foliation with the $\mathrm{x}$ axis parallel to the $\mathrm{L}_{2}$ lineation; the $\mathrm{z}$ axis is perpendicular to this plane and normal to the pole figures). This asymmetry, noted for both c- and a-axis, confirms the dextral sense of shear as suggested by field and thin section observations. The distribution of the a-axis indicates an oblique shear plane to the foliation (analogous to S-C pairs in mylonites). The pattern for the c-axis is similar to a type-I crossed girdle (Lister 1977, Price 1985, Passchier and Trouw 1996) inclined relatively to the reference axis. The preferential development of the smaller arm in the NW quadrant in relation to the SE quadrant is due to the difference in size in the domains of rotation of the material lines, which is a typical effect of non-coaxial deformation (Passchier and Trouw 1996). The distribution of the axis from the border to the center of the pole figures also suggests a high activity in the basal and rhombic planes, but low to no activity at all in the prismatic plane. The fabric skeleton allows inferring that these rocks were formed in a low temperature regimen, under low metamorphic grade (Passchier and Trouw 1996).

A very specific refolding style can be found in some outcrops of the Central Compartment. The older folds have $S_{2}$ as axial plane, are very tight to isoclinal, and horizontal normal. $\mathrm{S}_{2}$ strongly overprints the folded $\mathrm{S}_{1} / / \mathrm{S}_{0}$ surfaces. The hinge zones are rarely visible, thus outcrops in general show a vertical to highly steep $\mathrm{S}_{2} / / \mathrm{S}_{1} / / \mathrm{S}_{0}$ surface.
Upon these older folds, a later folding event generated open, horizontal inclined to recumbent folds, with $\mathrm{S}_{3}$ as a fan-geometry axial plane. The interference figure generated corresponds to the type 3 of Ramsay (1967). The modal maxima for the b2 $\left(\mathrm{S} 55^{\circ} \mathrm{W} / 08^{\circ}\right)$ and $\mathrm{b} 3\left(\mathrm{~N} 81^{\circ} \mathrm{E} / 03^{\circ}\right)$ axis, and the constructed axis for the folding of $\mathrm{S}_{0} / / \mathrm{S}_{1}$ in the Central Compartment $\left(\mathrm{N} 22^{\circ} \mathrm{W} / 14^{\circ} \mathrm{SW}\right)$ confirm this nearly coaxial nature (Figure $5 \mathrm{~d}$, f and h; see also Caxito 2010).

\section{NORTHERN COMPARTMENT}

In the Northern Compartment, NE-SW trending lineaments predominate, in both the schists of the Formosa Formation and gneisses of the Cristalândia do Piauí Complex. The typical structure of this compartment is the $\mathrm{S}_{2}$ crenulation foliation dipping in low angles to the southeast $\left(\mathrm{N} 49^{\circ} \mathrm{E} / 15^{\circ} \mathrm{SE}\right)$, with a ramp and platform thrusting geometry verging towards northwest (Figure $4 \mathrm{e}$ ). Oblique $\mathrm{L}_{2}$ $\left(\mathrm{N} 67^{\circ} \mathrm{E} / 07^{\circ}\right)$ characterizes predominantly dextral oblique kinematics (Figure 3a).

$\mathrm{S}_{0} / / \mathrm{S}_{1}$ is rarely visible at the Northern Compartment, due to the strong overprinting by $\mathrm{S}_{2}$ and due to the effects of a higher degree of metamorphism than that of the former compartments, reaching the transition between the greenschist and amphibolite facies. $\mathrm{S}_{3}$ outcrops occasionally, without a significative change of attitude in regards to the other compartments (Figure $5 \mathrm{~g}$ ).

It is common to find slices of gneisses from the Cristalândia do Piauí Complex tectonically interleaved within the schists of the Formosa Formation in the Northern Compartment, thus suggesting a low preserved thickness of the metasedimentary package. The structural and microstructural relations of the garnet-mica schists in contact with the gneisses suggest frontal to oblique thrust shear zones, with top-to-northwest reverse kinematics. The low angles of dip of the penetrative $S_{2}$ foliation might suggest expressive displacement through northwest-verging nappes. 

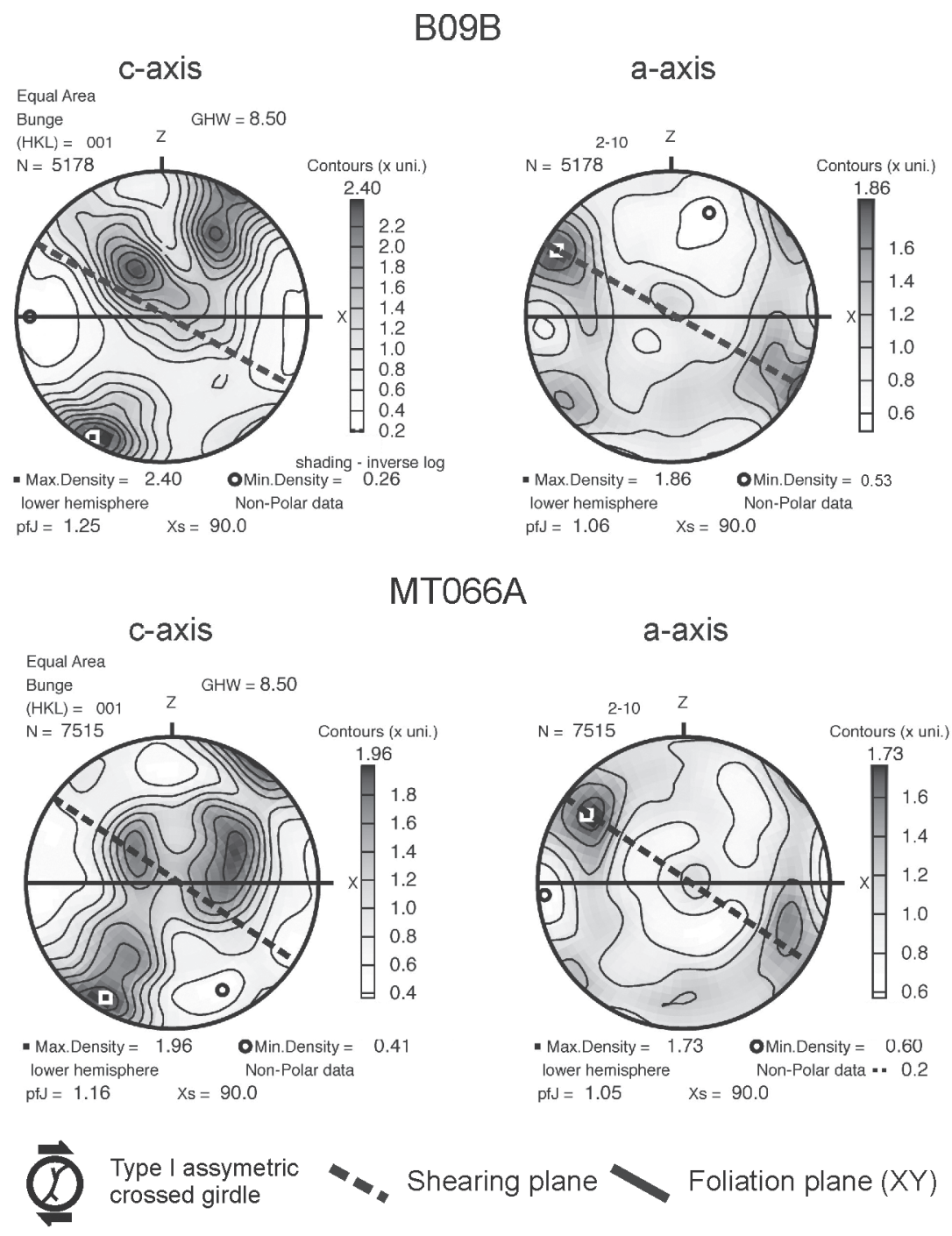

Figure 7 - Isoareal pole figures for the crystallographic axis orientation (LPO) of quartz grains for samples of the Central Compartment.

\section{DISCUSSION AND CONCLUSIONS}

The structural data acquired suggests a polyphasic evolution related to the Brasiliano Orogeny $(\sim 600$ $540 \mathrm{Ma}$ ), as demonstrated by the K-Ar mineral ages of Egydio-Silva (1987). Three main progressive deformational phases (sensu Passchier and Trouw 1996) can be distinguished:

Phase $D_{1}$ - Development of the $\mathrm{S}_{1}$ penetrative foliation, which is generally parallel to $\mathrm{S}_{0}$. Little can be said about the structures and tectonic meaning of this phase, due to the lack of data and generalized posterior transposition.
Phase $D_{2}$ - Development of the penetrative $\mathrm{S}_{2}$ crenulation foliation and associated lineations, besides the remarkable doubly-vergent asymmetrical fan structure of the Rio Preto fold belt. This phase generated folds in a gradient of style which varies from smooth and concentric in the cratonic Bambuí Group (Egydio-Silva 1987), progressively becoming tighter in the proximities of the Caripare Shear Zone, and finally similar tight to isoclinal, partially to totally transposed folds, within the fold belt area. This phase also generated the major brittle/ductile structures of the fold belt, such as the 
Cariparé and Malhadinha/Rio Preto shear zones. The main metamorphic event is cogenetic to phase D2.

Phase $D_{3}$ - Generation of $\mathrm{S}_{3}$ spaced crenulation cleavage, dipping southeast. This foliation is associated to northwest-verging thrust faults, and possibly to fracturing observed both in outcrop and aerial imagery scale. Thus, phase D3 possibly represents a final compressive phase, dominated by northwest-verging structures, i.e. towards the hinterland. These structures were generated in a brittle-ductile regime, without significant blastesis, in a shallower crustal level than D2.

Based on both empirical and experimental studies, a number of models have been proposed to explain the development of doubly-vergent fan structures in fold belts. Some authors (e.g. Sylvester and Smith 1976, Woodcock and Schubert 1994) consider that the movement on strike-slip and oblique faults within the crystalline basement reflects in a typical extrusive structure in the sedimentary cover. It is important to observe, however, that the term "flower structure" was originally proposed for outcrop- and seismic section-scale brittle structures, and for this reason it is preferable to use the term divergent (or doublyvergent) fan for the kilometric, ductile structure of the Rio Preto fold belt.

McClay et al. (2004) performed experiments utilizing analogical models emulating the development of divergent fold and thrust belts, through the variation of the interaction angle between two lithospheric blocks in a destructive regime. These authors showed that using low angles between the contact of the two blocks and the main $\sigma 1$ tension $\left(\sim 30^{\circ}\right)$, pseudo-flower structures develop, whose central portion is demarked by an anastomosing fault zone where strike-slip and oblique shear zones develop in the sedimentary cover. In this model, the progressive deformation starts with the development of a thrust front towards the foreland and always with the development of minor back-thrusting front towards the hinterland.
The transpressive structures in the central portion of the fold belt are all developed later in the experiment. In other words, the divergent structure is generated by the nucleation of thrusts and back-thrusts in the initial stages of progressive deformation, with the development of transpressive zones in the late stage, when deformation can no longer be accommodated by tangential tectonics. The scale and asymmetry of the fan structure and the degree of development of the directional structures depend mostly on the angle between the margins of the interacting blocks and the main tension, although in real situations other factors can also affect it, such as the presence of structural buttresses and backstops of varied relative rigidity and the friction coefficient between the basement and the sedimentary cover.

Thus, we propose that the doubly-vergent asymmetric fan structure of the Rio Preto fold belt was generated during the oblique convergence between the São Francisco craton to the south and the Cristalândia do Piauí block to the north. These two blocks interacted in a clockwise sense of motion, first generating the thrusts and back-thrusts of the Southern and Northern compartments, respectively. In the final stages of collision, deformation was then accommodated by the strike-slip to oblique movements on the Central Compartment, generating the Malhadinha-Rio Preto shear zone system at the central portion of the fold belt.

One question which remains open refers to the driving force of the collision between the two blocks. Up to date, no oceanic or orogenic igneous rocks of Brasiliano age were found within the Rio Preto fold belt, which precludes the interpretation of an accretionary orogenic process. This leaves two possible explanations: 1) these orogenic remnants are hiding behind the Parnaíba basin Paleozoic sedimentary rocks, which cover much of the fold belt to the north; 2) the Rio Preto fold belt represents the inversion of an intracontinental fold 
belt (e.g. an inverted rift). With regard to the second option, there are many examples of intracontinental deformation belts that extend for hundreds of kilometers in the vicinities of major orogenic areas, in effect generating kilometric tranpressive structures such as pop-ups and pseudo-flowers (e.g. Storti et al. 2003); and thus deformation within the Rio Preto fold belt area could be the reflection of orogenic processes occuring further North (within the Borborema Province) and West (within the Tocantins Province), far away from its present outcrop area.

\section{ACKNOWLEDGMENTS}

We are grateful to Conselho Nacional de Desenvolvimento Científico e Tecnológico (CNPq) (Process $n^{\circ}$ 475510/2008-9) and Fundação de Amparo à Pesquisa do Estado de Minas Gerais (FAPEMIG) (CRA 505-06) for the financial support, and the latter for providing scholarship for the first author Master's. We would also like to thank geologist Felipe Rodrigues Martins for his assistance in field.

\section{RESUMO}

A faixa dobrada Rio Preto bordeja a margem noroeste do cráton do São Francisco e mostra uma estrutura singular quilométrica de leque assimétrico de dupla vergência, com evolução estrutural polifásica atribuída exclusivamente à Orogênese Brasiliana ( 600-540 Ma). A faixa dobrada pode ser subdividida em três compartimentos estruturais: Os Compartimentos Norte e Sul com uma tendência geral na direção NE-SW, separados pelo Compartimento Central de tendência aproximadamente E-W. A mudança de mergulho de $\mathrm{S}_{2}$, uma clivagem de crenulação apertada que é a principal estrutura da faixa dobrada, entre os três compartimentos, caracteriza a estrutura em leque. O Compartimento Central é caracterizado por quartzitos miloníticos sub-verticais, que materializam um sistema de zonas de cisalhamento direcionais de baixa-T (Zona de Cisalhamento de Malhadinha - Rio Preto) que corta a porção central da faixa dobrada. Em comparação a modelos análogos publicados, considera-se que a estrutura única da faixa Rio Preto foi gerada pela interação oblíqua destrógira entre o bloco de Cristalândia do Piauí a norte e o cráton do São Francisco a sul.

Palavras-chave: Orogênese Brasiliana, leque de dupla vergência, faixa Rio Preto, cráton do São Francisco, análise estrutural.

\section{REFERENCES}

AlKMIM FF. 2004. O que faz de um cráton um cráton? O Cráton do São Francisco e as revelações almeidianas ao delimita-lo. In: Mantesso-Neto V, Bartorelli A, Carneiro CDR and Brito-Neves BB (Orgs), Geologia do Continente Sul-Americano: evolução da obra de Fernando Flávio Marques de Almeida, Beca, São Paulo, p. 17-35.

AlmeIDA FFM. 1977. O Cráton do São Francisco. Revista Brasileira de Geociências 7: 349-364.

CAXITO FA. 2010. Evolução tectônica da Faixa Rio Preto, noroeste da Bahia / sul do Piauí. Masters dissertation, IGC-UFMG, $151 \mathrm{p}$

Caxito FA, Dantas EL, Stevenson R And Uhlein A. 2014. Detrital zircon (U-Pb) and $\mathrm{Sm}-\mathrm{Nd}$ isotope studies of the provenance and tectonic setting of basins related to collisional orogens: The case of the Rio Preto fold belt on the northwest São Francisco craton margin, NE Brazil. Gondwana Research 26(2): 741-754. http://dx.doi. org/10.1016/j.gr.2013.07.007

Caxito FA, Halverson GP, Uhlein A, Stevenson R, GonÇALVES Dias T AND UhleIN GJ. 2012b. Marinoan glaciation in east central Brazil. Precambrian Research 200-203: 38-58. http://dx.doi.org/10.1016/j.precamres. 2012.01.005

CAXito FA, Uhlein A, SANglard JCD, GonÇAlves Dias T AND Mendes MCO. 2012a. Depositional systems and stratigraphic review proposal of the Rio Preto fold belt, northwestern Bahia / southern Piauí. Revista Brasileira de Geociências 42(3): 523-538.

EgYdio-Silva M. 1987. O sistema de dobramentos Rio Preto e suas relações com o Cráton São Francisco. Tese de doutorado, IGC-Universidade de São Paulo, São Paulo, $95 \mathrm{p}$.

EgYdio-Silva M, KaRMANN I AND TROMPETte RR. 1989. Litoestratigrafia do Supergrupo Espinhaço e Grupo Bambuí no NW do estado da Bahia. Revista Brasileira de Geociências 19(2): 101-112.

Gonçalves Dias T AND Mendes MCO. 2008. Geologia da Faixa Rio Preto entre Formosa do Rio Preto e Malhadinha, Bahia. Trabalho de Graduação, IGC - UFMG, Belo Horizonte, $62 \mathrm{p}$.

KoONS PO. 1990. Two sided orogens: collision and erosion from sandbox to the Southern Alps, New Zealand. Geology 18: 679-682. 
LISTER GS. 1977. Discussion: crossed-girdle c-axis fabrics in quartzites plastically deformed by plane strain and progressive simple shear. Tectonophysics 39: 51-54.

MCClay KR And Whitehouse P. 2004. Analogue models of doubly convergent orogens. In: McClay KR (Ed), Thrust tectonics and hydrocarbon systems. AAP Geologists Memoir 82.

MCClay KR, Whitehouse PS, DOOLEY T AND RichaRdS M. 2004. 3D evolution of fold and thrust belts formed by oblique convergence. Marine and Petroleum Geology 21: 857-877.

PASSChIER CW AND TROUW RAJ. 1996. Microtectonics. Berlim, Springer-Verlag, 289 p.

PRICE GP. 1985. Preferred Orientations in Quartzites. In: Wenk HF (Ed), Preferred orientations in deformed metals and rocks: an introduction to modern texture analysis. Academic Press Inc, New York, p. 385-406.
RAMSAY JG. 1967. Folding and Fracturing of Rocks. McGrawHill, New York, 568 p.

STORTI F, HOLDSWORTH RE AND SALVINI F. 2003 (EDS). Intraplate strike-slip deformation belts. The Geological Society, London, $237 \mathrm{p}$.

SYLVESTER AG AND SMITH RR. 1976. Tectonic transpression and basement-controlled deformation in San Andreas Fault Zone, Salton Trough, California. AAPG Bulletin 60(12): 2081-2102.

Willett S, BeAumont C AND FulLsack P. 1993. Mechanical model for the tectonics of doubly-vergent compressional orogens. Geology 21: 371-374.

WoOdCOCK NH AND SCHUBERT C. 1994. Continental strikeslip tectonics. In: Hancock PL (Ed), Continental Tectonics, Pergamon Press, Oxford, p. 251-263. 